\title{
OVERESTIMATING THE ROLE OF TOURISM IN RURAL AREAS ON THE EXAMPLE OF SELECTED REGIONS IN POLAND AND CROATIA
}

\author{
Denis CERIĆ \\ Institute of Geography and Spatial Organization, Polish Academy of Sciences \\ Twarda 51/55, 00-818 Warsaw \\ d.ceric@twarda.pan.pl
}

\begin{abstract}
Rural tourism is often found as a solution for all problems or difficulties for the structural problems of rural areas. Many local strategies of the rural areas have included development of tourism as one of their main goals and as a result various financial programs were prepared and conducted in order to support development of tourism. Despite of some positive changes, the results in general are not satisfying.

Based on scientific literature and statistical data, the paper is critically examining the role of tourism in rural areas on the example of rural municipalities in selected EU NUTS-2 regions in Poland and Croatia. The role of tourism is researched through the change of the tourist density ratio and the tourist intensity rate indexes, which are calculated for every single municipality of the researched area for 2004 and 2013. Despite significant governmental and local initiatives, minor positive changes of measured tourist indexes that occurred in rural areas made the author argue how the potential socio-economic role of tourism in rural areas is fairly overestimated. The purpose of this paper is to provoke scientific discussion on artificial developing of tourism in rural areas which are not pre-determined for tourism.
\end{abstract}

Key words: rural areas, tourist density ratio, tourist intensity rate, Mazovian Voivodeship, Continental Croatia.

\section{Introduction}

Rural tourism is an important factor in activating and sustainable development of rural areas. It helps preserve the local identity, traditions and customs, protects the environment, strengthens indigenous, traditional and organic farming and helps in developing rural areas based on sustainable development. Therefore, the various practitioners complaining about the underestimated tourism potential of rural areas is justified. However, is it possible to solve all of the problems in every rural area by developing tourism there? Tourism and recreation have been for decades one of the responses to various challenges and threats to rural areas, often even a solution for all structural problems of the rural areas (Adamowicz 2010; Baležentis et al. 2012; Baum 2011; Butler et al. 1998; Cawley and Gillmor 2008; Hall et al. 2003; Ilbery 1998; Látková and Vogt 2011; Lukić 2013; Sharpley 2002; Wilson et al. 2001; Woods 2005). Literature which examines the role of tourism in rural areas in Poland and Croatia is still limited in scope in comparison with the western 
European countries. Moreover, western literature research results on this field could not be easily transferred to the Central and Eastern European countries due to their different historical background of rural and overall development. S. Baum (2011) argues that nearly all the Central and Eastern European countries have pinned their hopes on the development of tourism in rural areas since the beginning of transition, but a comprehensive analytical framework of the tourist potential for this area in this part of the world is still missing. The question of overestimating the potential of Polish rural areas in terms of tourism is discussed by the same author - she argues that the economic significance of tourism in most rural areas outside the traditional tourist destinations in Poland is still marginal, and that the future tourist potential of rural areas in Poland is limited (Baum 2011). Croatian authors are not as critical in future prognoses of tourism in rural areas of Croatia. However, empirical results of their research reveal not satisfactory results of recent development (see Demonja 2014; Krajnović et al. 2011). All of the mentioned authors belong to a minor group of those who argue on the overestimated potential and role of tourism in rural areas.

Both in Poland and in Croatia, numerous different level strategies include development of tourism as one of the main goals. The most recent national strategies of tourism development emphasize development of tourism in rural areas. According to the new Program of tourism development proposed by the Polish Ministry of Sport and Tourism in 2015, development of tourism in rural areas is detected as one of the five priority areas for development and promotion in the perspective until 2020 (Program rozwoju turystyki... 2015). In the new Croatian strategy of tourism development until 2020, the current development of tourism in rural areas is characterized as "extremely slow" (Strategija razvoja turizma... 2013, s. 9), and therefore one of the ten main strategic areas of tourist offer and tourist product development is its support in rural areas, as well. As a consequence, various financial programs will be prepared and conducted in order to support development of tourism in rural areas. There would be no problem with the mentioned intentions, if they were something new. Unfortunately, the above stated goals are being repeated from perspective to perspective and yet no appropriate tools or models have been discovered which could help develop tourism in rural areas on the scale that could have some greater influence on development of the area itself. As an example, the previous strategy of tourism development in Croatia has identified development of tourism in rural areas as one of the priorities as well. As a result of it, 19 forms of tourism were listed to have conditions for the development in Croatian rural areas and 3 financial programs were introduced (Strategija razvoja... 2003). What are the results of those programs? The dynamics of stronger development is noticed, but its impact on the overall situation in rural areas is very questionable. Could we be satisfied with "extremely slow" development?

In this paper, using a simple measure of tourist traffic dynamics in specified rural areas of two comparable regions of Poland and Croatia between 2004 and 2013, the author tries to answer the questions: whether the number of tourists has changed over the last decade, in which direction and in which amounts. Empirical research could confirm or reject the main research hypothesis: despite the fast growth of tourism in rural areas during the last decade, the role of tourism is still insufficient to be treated as a solution for structural problems or difficulties of those areas. 


\section{Methodology}

The objective of the research was to obtain an empirical evidence for insufficient role of tourism in rural areas. Analysis of the changes in tourist arrivals to selected NUTS 2 Central European regions on the level of rural municipalities during the last decade has been done for this purpose, as well as an analysis of the following tourism indicators: Tourism Density Ratio (TDR) and Tourist Intensity Rate (TIR). Those results were later confronted with the results of the regional and national averages. Municipalities where the selected indicators have registered values above the national averages stand out, and an attempt was made at explaining the function of tourism in those municipalities. In the discussion part, empirical evidence was with experts' opinions.

Desk research was the main method used in the research. The Tourist Density Ratio (TDR) is used as an indicator of the impact of tourists on space. TDR is calculated as follows:

$$
T D R=T / S \text {, }
$$

where $T$ stands for the number of tourists, while $S$ stands for the area in square kilometers. The Tourist Intensity Rate (TIR) measures the impact of tourism on the society and culture of the local population, since it stands for the number of tourists per 100 inhabitants:

$$
T I R=T / L^{*} 100
$$

$T$ stands for the number of tourists, while $L$ stands for the population number in the selected area.

Basic research materials were national and regional statistical publications published in online databases, such as the Local Data Bank for Poland (Bank Danych Lokalnych 2015) or the Croatian Bureau of Statistics for Croatia (Državni zavod... 2015).

The timeframe of research: 2004 and 2013, since it presents the last decade of accessible official data for both countries on municipality level. Both in Poland and in Croatia, stronger development of tourism in rural areas occurred in 2000, because of numerous activities employed from the local and national governments to support development of tourism there.

Rural areas of the two European NUTS 2 regions, the Mazovian Voivodeship (województwo mazowieckie) in Poland and the Continental Croatia (Kontinentalna Hrvatska), in Croatia, are chosen for the spatial frame of the research. Both regions are similar in size, number of administrative units and density of rural areas. Those regions mostly consist of lowland areas without mountainous or sea-shore areas with a function of extraordinary tourist attraction. Both regions include the capital city of the country as well (Tab. 1, Fig. 1).

Rural areas are defined differently in the countries included in the research. In the case of Poland, delimitation of rural areas provided by National Statistics Bureau's definition is followed: rural areas are areas located outside the administrative borders of cities, meaning areas of rural communes and rural portion, lying outside the city, urban-rural commune (Bank Danych Lokalnych 2015). Croatian delimitation of rural areas in this research is based on administrative criteria as well, where municipalities represent the smallest administrative units, considered by the national administrative delimitation as rural areas (Državni zavod... 2015). There are no urban, rural or urban-rural communities in Croatia, there are just municipalities and the cities, and they are considered as rural and urban areas, respectively. 
Table 1. Comparison of the Mazovian Voivodeship and the Continental Croatia NUTS 2 regions

\begin{tabular}{|c|c|}
\hline POLAND & CROATIA \\
\hline Mazovian Voivodeship & Continental Croatia \\
\hline 1 of 16 NUTS 2 regions within the country & 1 of 2 NUTS 2 regions within the country \\
\hline 5 cities +37 land counties & 1 city +37 land counties \\
\hline $\begin{array}{l}314 \text { administrative units: municipalities ( } 35 \text { urban } \\
+50 \text { urban-rural + } 229 \text { rural) }\end{array}$ & $\begin{array}{l}336 \text { administrative units ( } 67 \text { towns } \\
+269 \text { municipalities) }\end{array}$ \\
\hline 35,558 square km & 31,889 square km \\
\hline pop. $5,285,604$ & pop. $2,872,954$ \\
\hline density: 148.6 & density: 90.1 \\
\hline density of rural areas: 56.7 & density of rural areas: 42.0 \\
\hline
\end{tabular}

Source: own elaboration based on the Bank Danych Lokalnych 2015; Državni zavod... 2015.
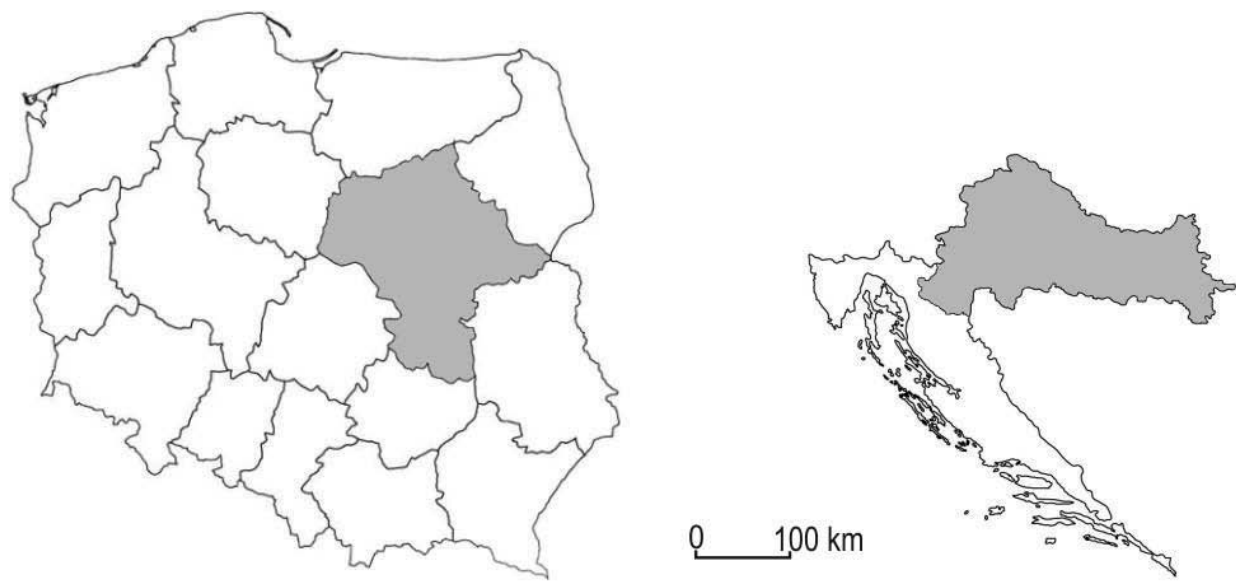

Fig. 1. The Mazovian Voivodeship and Continental Croatia position within Poland and Croatia Source: own elaboration.

\section{Results}

Out of the 269 rural administration units in Continental Croatia, only 54 recorded tourist arrivals in 2013 (Tab. 2). Between 2004 and 2013, the number of tourist increased by 24.6 percent, same as the measured tourism indicators TDR and TIR. However, this growth is slower than the growth of country arrivals and indicators -32.2 percent, while the values of TDR and TIR were 4.8 and 2.5 times lower than the country averages for 2013, respectively. Moreover, calculation of the absolute values of the TDR and TIR indicators and their comparison to the national average in 2004 shows that the results achieved by those rural units in 2004 were better than those of 2013, since the TDR was 4.5 and the TIR 2.3 times lower than the national average in 2004.

In the Mazovian Voivodeship, 83 out of 229 rural administrative units recorded tourist arrivals in 2013 (Tab. 2). During the research period, the number of tourist arrivals grew by 153.0 percent, which is twice the national growth. The TIR indicator value grew from 
19.5 in 2004 to 49.2 in 2013, representing a jump from below the national average to a little above it. However, the TDR indicator value of 37.3 remains lower than the national average of 55.5 also in 2013.

Table 2. Comparison of general data on the area, population, density, No. of tourists, the TDR and TIR indicators for 2004 and 2013 for: a) countries, b) selected NUTS 2 regions, c) rural areas of selected NUTS 2 regions, and d) administrative units in rural areas of selected NUTS 2 regions where tourism is recorded

a) Countries

\begin{tabular}{|c|c|c|c|c|c|}
\hline & Year & \multicolumn{2}{|c|}{ Poland } & \multicolumn{2}{|c|}{ Croatia } \\
\hline Area (square km) & 2011 & \multicolumn{2}{|c|}{312,679} & \multicolumn{2}{|c|}{56,594} \\
\hline Population & 2011 & \multicolumn{2}{|c|}{$38,358,447$} & \multicolumn{2}{|c|}{$4,284,899$} \\
\hline Density (pop./sq km) & 2011 & \multicolumn{2}{|c|}{123.3} & \multicolumn{2}{|c|}{75.7} \\
\hline \multirow{2}{*}{ No. of tourists } & 2004 & $9,884,800$ & \multirow{2}{*}{$+75.5 \%$} & $9,412,276$ & \multirow{2}{*}{$+32.2 \%$} \\
\hline & 2013 & $17,351,968$ & & $12,441,476$ & \\
\hline \multirow{2}{*}{ TDR } & 2004 & 31.6 & \multirow{2}{*}{$+75.6 \%$} & 166.5 & \multirow{2}{*}{$+32.1 \%$} \\
\hline & 2013 & 55.5 & & 220.0 & \\
\hline \multirow{2}{*}{ TIR } & 2004 & 25.6 & \multirow{2}{*}{$+75.8 \%$} & 219.7 & \multirow{2}{*}{$+32.2 \%$} \\
\hline & 2013 & 45.0 & & 290.4 & \\
\hline
\end{tabular}

b) Selected NUTS 2 regions

\begin{tabular}{|c|c|c|c|c|c|}
\hline & Year & \multicolumn{2}{|c|}{ Mazovian Voivodeship } & \multicolumn{2}{|c|}{ Continental Croatia } \\
\hline Area (square km) & 2011 & \multicolumn{2}{|c|}{35,558} & \multicolumn{2}{|c|}{31,889} \\
\hline Population & 2011 & \multicolumn{2}{|c|}{$5,285,604$} & \multicolumn{2}{|c|}{$2,872,954$} \\
\hline Density (pop./sq km) & 2011 & \multicolumn{2}{|c|}{148.6} & \multicolumn{2}{|c|}{90.1} \\
\hline \multirow{2}{*}{ No. of tourists } & 2004 & $1,696,041$ & \multirow{2}{*}{$+94.5 \%$} & 935,344 & \multirow{2}{*}{$+60.9 \%$} \\
\hline & 2013 & $3,298,426$ & & $1,504,747$ & \\
\hline \multirow{2}{*}{ TDR } & 2004 & 47.7 & \multirow{2}{*}{$+94.5 \%$} & 29.3 & \multirow{2}{*}{$+61.1 \%$} \\
\hline & 2013 & 92.8 & & 47.2 & \\
\hline \multirow{2}{*}{ TIR } & 2004 & 32.1 & \multirow{2}{*}{$+94.4 \%$} & 32.6 & \multirow{2}{*}{$+60.8 \%$} \\
\hline & 2013 & 62.4 & & 52.4 & \\
\hline
\end{tabular}

c) Rural areas of selected NUTS 2 regions

\begin{tabular}{|c|c|c|c|c|c|}
\hline & Year & \multicolumn{2}{|c|}{ Mazovian Voivodeship } & \multicolumn{2}{|c|}{ Continental Croatia } \\
\hline No. of admin. units & 2013 & \multicolumn{2}{|c|}{229} & \multicolumn{2}{|c|}{269} \\
\hline Area (square km) & 2011 & \multicolumn{2}{|c|}{33,401} & \multicolumn{2}{|c|}{20,368} \\
\hline population & 2011 & \multicolumn{2}{|c|}{$1,892,561$} & \multicolumn{2}{|c|}{855,883} \\
\hline Density (pop./sq km) & 2011 & \multicolumn{2}{|c|}{56.7} & \multicolumn{2}{|c|}{42.0} \\
\hline \multirow{2}{*}{ No. of tourists } & 2004 & 142,278 & \multirow{2}{*}{$+153.0 \%$} & 196,659 & \multirow{2}{*}{$+24.6 \%$} \\
\hline & 2013 & 359,960 & & 244,984 & \\
\hline \multirow{2}{*}{ TDR } & 2004 & 4.3 & \multirow{2}{*}{$+151.0 \%$} & 9.7 & \multirow{2}{*}{$+23.7 \%$} \\
\hline & 2013 & 10.8 & & 12.0 & \\
\hline \multirow{2}{*}{ TIR } & 2004 & 7.5 & \multirow{2}{*}{$+153.3 \%$} & 23.0 & \multirow{2}{*}{$+24.2 \%$} \\
\hline & 2013 & 19.0 & & 28.6 & \\
\hline
\end{tabular}


d) Administrative units in rural areas of selected NUTS 2 regions where tourism is recorded

\begin{tabular}{|c|c|c|c|c|c|}
\hline & Year & \multicolumn{2}{|c|}{ Mazovian Voivodeship } & \multicolumn{2}{|c|}{ Continental Croatia } \\
\hline No. of admin. units & 2013 & \multicolumn{2}{|c|}{83} & \multicolumn{2}{|c|}{54} \\
\hline Area (square km) & 2011 & \multicolumn{2}{|c|}{9,661} & \multicolumn{2}{|c|}{5,292} \\
\hline Population & 2011 & \multicolumn{2}{|c|}{731,086} & \multicolumn{2}{|c|}{209,162} \\
\hline Density (pop./sq km) & 2011 & \multicolumn{2}{|c|}{75.7} & \multicolumn{2}{|c|}{39.5} \\
\hline \multirow{2}{*}{ No. of tourists } & 2004 & 142,278 & \multirow{2}{*}{$+153.0 \%$} & 196,659 & \multirow{2}{*}{$+24.6 \%$} \\
\hline & 2013 & 359,960 & & 244,984 & \\
\hline \multirow{2}{*}{ TDR } & 2004 & 14.7 & \multirow{2}{*}{$+153.7 \%$} & 37.2 & \multirow{2}{*}{$+24.5 \%$} \\
\hline & 2013 & 37.3 & & 46.3 & \\
\hline \multirow{2}{*}{ TIR } & 2004 & 19.5 & \multirow{2}{*}{$+152.3 \%$} & 94.0 & \multirow{2}{*}{$+24.6 \%$} \\
\hline & 2013 & 49.2 & & 117.1 & \\
\hline
\end{tabular}

Source: own elaboration based on Bank Danych Lokalnych 2015; Državni zavod... 2015.

In order to isolate the administrative units with a stronger tourism function, an analysis was carried out at municipality level. This analysis showed that in Continental Croatia only 3 of 269 rural municipalities recorded the TDR indicator value above the national average (Tab. 3), while only 4 recorded the TIR indicator value above the national average in 2013 (Tab. 4). Deeper analysis suggested that those municipalities have very little in common with rural tourism, since three of them have a Spa centre with thermal waters and large hospitals built during the period of socialism - municipalities Tuhelj, Sveti Martin na Muri and Topusko. The fourth one-Rakovica, is a municipality in the vicinity of the Plitvice Lakes National Park, the most visited national park in Croatia which itself has very limited accommodation facilities and therefore visitors are usually accommodated in the municipalities close to it.

Table 3. Administrative units with the TDR indicator above the national average in 2013

\begin{tabular}{|c|c|c|c|c|c|c|}
\hline \multirow{2}{*}{ Country } & \multirow{2}{*}{$\begin{array}{l}\text { NUTS2 } \\
\text { region }\end{array}$} & \multirow{2}{*}{$\begin{array}{c}\text { National } \\
\text { TDR average }\end{array}$} & \multirow{2}{*}{$\begin{array}{l}\text { Total nr of } \\
\text { rural ad- } \\
\text { min. units }\end{array}$} & \multicolumn{3}{|c|}{ Rural admin. units with TDR above national average } \\
\hline & & & & $\mathrm{nr}$ & name of administrative unit & value \\
\hline Poland & $\begin{array}{l}\text { Mazovian } \\
\text { Voivodeship }\end{array}$ & 55.5 & 229 & 12 & $\begin{array}{l}\text { Raszyn } \\
\text { Serock - obszar wiejski } \\
\text { Michałowice } \\
\text { Radziejowice } \\
\text { Stare Babice } \\
\text { Łąck } \\
\text { Nieporęt } \\
\text { Chlewiska } \\
\text { Lesznowola } \\
\text { Wiązowna } \\
\text { Żabia Wola } \\
\text { Sochocin }\end{array}$ & $\begin{array}{r}845.0 \\
620.5 \\
419.4 \\
357.7 \\
208.0 \\
176.9 \\
149.1 \\
83.3 \\
69.7 \\
68.5 \\
61.8 \\
60.4\end{array}$ \\
\hline Croatia & $\begin{array}{l}\text { Continental } \\
\text { Croatia }\end{array}$ & 220.0 & 269 & 3 & $\begin{array}{l}\text { Tuhelj } \\
\text { Sveti Martin na Muri } \\
\text { Rakovica }\end{array}$ & $\begin{array}{r}1,241.8 \\
1,178.3 \\
492.7\end{array}$ \\
\hline
\end{tabular}

Source: own elaboration based on Bank Danych Lokalnych 2015; Državni zavod... 2015. 
Table 4. Administrative units with the TIR indicators above the national average in 2013

\begin{tabular}{|c|c|c|c|c|c|c|}
\hline \multirow{2}{*}{ Country } & \multirow{2}{*}{$\begin{array}{l}\text { NUTS2 } \\
\text { region }\end{array}$} & \multirow{2}{*}{$\begin{array}{l}\text { National } \\
\text { TIR average }\end{array}$} & \multirow{2}{*}{$\begin{array}{l}\text { Total nr of } \\
\text { rural ad- } \\
\text { min. units }\end{array}$} & \multicolumn{3}{|c|}{ Rural admin. units with TIR above national average } \\
\hline & & & & $\mathrm{nr}$ & name of administrative unit & value \\
\hline Poland & $\begin{array}{l}\text { Mazovian } \\
\text { Voivodeship }\end{array}$ & 45.0 & 229 & 25 & $\begin{array}{l}\text { Serock - obszar wiejski } \\
\text { Radziejowice } \\
\text { Łąck } \\
\text { Raszyn } \\
\text { Chlewiska } \\
\text { Sochocin } \\
\text { Wilga } \\
\text { Nieporęt } \\
\text { Słubice } \\
\text { Nowe Miasto nad Pilicą - obszar wiejski } \\
\text { Samaki } \\
\text { Osieck } \\
\text { Żabia Wola } \\
\text { Michałowice } \\
\text { Brańszczyk } \\
\text { Stare Babice } \\
\text { Białobrzegi - obszar wiejski } \\
\text { Wiązowna } \\
\text { Olszewo-Borki } \\
\text { Sierpc } \\
\text { Pilawa - obszar wiejski } \\
\text { Sobolew } \\
\text { Płońsk } \\
\text { Góra Kalwaria - obszar wiejski } \\
\text { Wieczfnia Kościelna }\end{array}$ & $\begin{array}{l}661.1 \\
499.5 \\
317.7 \\
175.5 \\
166.9 \\
123.9 \\
114.2 \\
109.4 \\
105.6 \\
94.0 \\
90.0 \\
88.8 \\
87.1 \\
86.8 \\
77.0 \\
76.5 \\
72.7 \\
62.0 \\
61.7 \\
58.6 \\
53.1 \\
52.8 \\
51.7 \\
49.7 \\
48.2\end{array}$ \\
\hline Croatia & $\begin{array}{l}\text { Continental } \\
\text { Croatia }\end{array}$ & 290.4 & 269 & 4 & $\begin{array}{l}\text { Rakovica } \\
\text { Tuhelj } \\
\text { Sveti Martin na Muri } \\
\text { Topusko }\end{array}$ & $\begin{array}{r}5,387.1 \\
1,475.5 \\
1,178.3 \\
391.5\end{array}$ \\
\hline
\end{tabular}

Source: own elaboration based on Bank Danych Lokalnych 2015; Državni zavod... 2015

In the Mazovian Voivodeship, a municipality level analysis showed that only 12 of 229 rural municipalities recorded the TDR indicator value above the national average. Considering the TIR indicator, 25 municipalities recorded its value above the national average in 2013. However, when compared with the Continental Croatia municipality values, only 4 Mazovian Voivodeship municipalities recorded the TDR value above the Croatian national average, while only 3 recorded the TIR value above it. Cumulative, those 5 municipalities are: Raszyn, Serock, Michałowice, Radziejowice and Łąck. Two of those municipalities are practically suburban zones of the Metropolitan City of Warsaw - Raszyn and Michałowice. Both have accessible public transport connections with the capital city and therefore it is assumed that tourists registered in these municipalities are mostly the tourists of the capital city. Moreover, Raszyn is a municipality in the vicinity of the Warsaw main airport. The third municipality - Serock is situated on the shores of the artificial Lake 
Zegrzyński, which is a recreational area for the inhabitants of Warsaw since the nineteen seventies. The municipality of Radziejowice is also close to Warsaw, but it is known for the water centrr Hamernia which attracts tourists, while Łąck is famous for forests and also lakes.

\section{Discussion}

Tourism in rural areas of Continental Croatia is present in administrative units inhabited by about one fourth of the regional rural population. It is developing extremely slowly. The number of tourists is growing at a pace slower than the national average. Therefore, tourism in Continental Croatia undoubtedly presented a marginal sector during the last decade and it could not be treated as a generator of change in the rural areas nor did it solve any structural problems or difficulties. It is also very questionable whether to expect that tourism in those areas will become so strong in the future, as to generate a better tomorrow.

In the Polish Mazovian Voivodship tourism is present in administrative units inhabited by about one third of the rural population. Moreover, the number of tourist arrivals and calculated indicators show greater development of tourism in the Mazovian Voivodship during the last decade, than was the case in the chosen Croatian region. The question is whether the presented values could be considered as sufficient for tourism to solve some structural problems or difficulties that those rural areas are experiencing?

The analysis showed that tourism in rural areas, outside the main tourist destinations which are pre-determined for tourism, is still indeed a small tourist segment. Rural tourism is definitely a significant factor in activation of the rural areas and it helps in preserving the local identities, traditions and customs, protects the environment, strengthens the indigenous, traditional and ecological production, and sometimes contributes to the development of rural areas based on sustainable development. But it cannot be treated as a tool or solution for structural problems of rural areas, since the volume and seasonality of tourism in those areas are often too limited. The role and the potential role of tourism in rural areas are often overestimated both by the local inhabitants and the public authorities. The strategies are being written, the funds are being set and used, but the results usually show minor improvements. However, the idea of developing tourism stands and the cycle is repeated over the decades. Maybe, in order to ensure a better life for the people who live there, the available financial resources could be re-allocated to some activities in those rural areas other than tourism?

S. Baum (2011) argues that the majority of regions - particularly outside of the traditional tourist destinations and far from big cities - will have to build their diversification on more pillars than tourism. However, many local strategies focus on tourism and particularly on the tourist infrastructure. R. Sharpley (2002) together with J.C. Dissart et al. argue that the availability of tourist infrastructure does not automatically lead to development of rural areas. S. Baum (2011) also argues that stimulation of the demand through marketing and image building is essential, while many authors agree as to the lack of professional marketing and promotional strategies in Poland (see Marciszewska 2006; Szwichtenberg 2009; Wyrzykowski 2000). However, marketing represents only one pillar of tourism. For example, poor accessibility causes tourists to escape to regions with a bet- 
ter accessibility (Więckowski et al. 2014). Apart from the tourist infrastructure, marketing and transport accessibility, the demand and approach to tourism together with education of the local inhabitants are of great importance. Rural tourism in Poland strongly depends on the development of the domestic demand (Baum 2011), but this demand is so far restricted by the high share of the population still living in rural areas and the pronounced family ties of city dwellers with the countryside (Kozak 2006). However, A.M.K. Nowaczek and D.A. Fennell (2002) argue that growth in urbanization and enhancement of environmental awareness in the Polish society could arouse interest in rural tourism in the future. But is is also necessary to provide education on tourism for the local population in rural Poland. In many rural areas in Poland the human resources are in a rather unfavourable condition thus hindering rural tourism development in the near future (Bański 2003). The latter author gives the following reasons: overaged population, out-migration, social frustration caused by high unemployment and low education levels. Not very well pronounced people's own initiative, the spirit of entrepreneurship and hospitality together with the lack of important entrepreneurial and tourism skills in many rural tourisr agencies in Poland observed by M. Augustyn (1998), and later confirmed by M.W. Kozak (2006). The Croatian case is very close to the Polish one. However, Croatian scholars are more focused on the inequality of rural tourism in the national regions (see Mišćin and Mađer 2008), or on analyses of the legislative frames, grants and programs for the development of rural tourism (see Demonja 2014). The literature on tourism in rural areas in Croatia is still insufficient.

Tourism can play an important role in rural areas if the above stated pillars are in balance, while keeping in mind the complexity, dynamic potential and fragility of the sector. All that means that the regions should establish local tourism management which should be strong, adjustable to new circumstances, and capable of taking quick decisions. It is utopia to expect that the natural and/or cultural heritage alone will attract tourists. If that heritage is exceptional, it is already attracting masses. If the masses are not there already, in the majority of cases it should not be thought that tourists are not there because of the lack of infrastructure or marketing, though this is the usual opinion expressed by the public and authorities.

\section{References}

Adamowicz J., 2010, Towards synergy between tourism and nature conservation. The challenge for the rural regions: The case of Drawskie Lake district, Poland, European Countryside, 2 (3), pp. 118-131, DOI: 10.2478/v10091-010-0009-1.

Augustyn M., 1998, National strategies for rural tourism development and sustainability: the Polish experience, Journal of Sustainable Tourism, 6 (3), pp. 191-209.

Baležentis T., Kriščiukaitienè I., Baležentis A., Garland R., 2012, Rural tourism development in Lithuania (2003-2010) - A quantitative analysis, Tourism Management Perspectives, 2-3, pp. 1-6, DOI: 10.1016/j.tmp.2012.01.001.

Bank Danych Lokalnych, 2015, (obtained from: http://stat.gov.pl/bdl/, 13.07.2015)

Bański J., 2003, Transforming the functional structure of Poland's rural areas, [in:] J. Bański and J. Owsiński (eds.), Alternatives for European Rural Areas, European Rural Development Network, Warsaw, pp. 19-37. 
Baum S., 2011, The Tourist Potential of Rural Areas in Poland, Eastern European Countryside, 17, pp. 107-135, DOI: 10.2478/v10130-011-0006-z.

Butler R., Hall C.M., Jenkins J., 1998, Tourism and Recreation in Rural Areas, John Wiley \& Sons, Chichester.

Cawley M., Gillmor D.A., 2008, Integrated Rural Tourism: Concepts and Practice, Annals of Tourism Research, 35 (2), pp. 316-337, DOI: 10.1016/j.annals.2007.07.011.

Demonja D., 2014, The Overview and Analysis of the State of Rural Tourism in Croatia, Sociologija i prostor, 52, 198,1, pp. 69-90, DOI: 10.5673/sip.52.1.4.

Dissart J.C., Vollet D., Poulhès O., Mallebay M., 2009, The landscape: a regional development factor that spurs territory - specific economic flows, Cemagref, FR, 1st International Conference on Landscape Economics, Vienna.

Državni zavod za statistiku, 2015, (obtained from: http://www.dzs.hr/, 17.07.2015).

Hall D., Roberts L., Mitchell M., 2003, New Directions in Rural Tourism, Ashgate, Aldershot.

Ilbery B., 1998, The Geography of Rural Change, Longman, Harlow.

Kozak M.W., 2006, Rola agroturystyki w rozwoju obszarów wiejskich. Stan i rekomendacje, Ekspertyza dla Ministerstwa Rozwoju Wsi i Rolnictwa, Warszawa.

Krajnović A., Čičin-Šajn D., Predovan M., 2011, Strateško upravljanje razvojem ruralnog turizma - problemi i smjernice, Oeconomica Jadertina, 1, pp. 30-45.

Látková P., Vogt C.A., 2011, Residents' Attitudes toward Existing and Future Tourism Development in Rural Communities, Journal of Travel Research, 51 (1), pp. 50-67, DOI: 10.1177/0047287510394193.

Lukić A., 2013, Tourism, farm diversification and plurality of rurality: Case study of Croatia, European Countryside, 4, pp. 356-376, DOI: 10.2478/euco-2013-0023.

Marciszewska B., 2006, Tourism in Poland: Changes in Policy, Management and Education, [in:] D. Hall, M. Smith and B. Marciszewska (eds.), Tourism in the New Europe, Wallingford: CABI, pp. 127-36.

Mišćin L., Mađer B., 2008, Aktualno stanje turizma na ruralnom prostoru Hrvatske 2008, Hrvatska gospodarska komora, Sektor za turizam, Zagreb, (obtained from: http://hgk.biznet.hr/hgk/fileovi/13081.ppt, 12.01.2016).

Nowaczek A.M.K., Fennell D.A., 2002, Ecotourism in post-communist Poland, Tourism Geographies, 4 (4), pp. 372-95.

Program rozwoju turystyki do 2020 roku, 2015, Ministerstwo Sportu i Turystyki, Warszawa, (obtained from: http://visitinowroclaw.pl/wp-content/uploads/2016/02/PROGRAM_ROZWOJU_TURYSTYKI_DO_2020_ROKU.pdf, 21.03.2016).

Sharpley R., 2002, Rural tourism and the challenge of tourism diversification: the case of Cyprus, Tourism Management, 23 (3), pp. 233-244, DOI: 10.1016/S0261-5177 (01)00078-4.

Strategija razvoja hrvatskog turizma do 2010. godine, 2003, Ministarstvo turizma, Zagreb, (obtained from: http://www.mint.hr/UserDocsImages/Strategija\%20hrvatskog\%20turizma\%20-\%20 finalna\%20verzija.pdf, 21.03.2016).

Strategija razvoja turizma Republike Hrvatske do 2020. godine, 2013, Vlada Republike Hrvatske, Zagreb, (obtained from: http://www.mint.hr/UserDocsImages/130426-Strategija-turizam-2020. pdf, 21.03.2016).

Szwichtenberg A., 2009, Activation of the Polish coastal tourist reception region using the instrument of a public-private partnership, Tourism, 19 (1-2), pp. 77-82.

Więckowski M., Michniak D., Bednarek-Szczepańska M., Chrenka B., Ira V., Komornicki T., Rosik P., Stępniak M., Székely V., Śleszyński P., Świątek D., Wiśniewski R., 2014, Road accessi- 
bility to tourist destinations of Polish-Slovak borderland: 2010-20130 prediction and planning, Geographia Polonica, 87 (1), pp. 5-26, DOI: 10.7163/GPol.2014.1

Wilson S., Fesenmaier D.R., Fesenmaier J., Van Es J.C., 2001, Factors for Success in Rural Tourism Development, Journal of Travel Research, 40 (2), pp. 132-138, DOI: 10.1177/004728750104000203.

Woods M., 2005, Rural Geography: Processes, Responses and Experiences in Rural Restructuring, Sage, London.

Wyrzykowski J., 2000, Conditions of Foreign Tourism Development in Central and Eastern Europe, [in:] J. Wyrzykowski (ed.), Changes in model of tourism in the last decade, Zakład Geografii Regionalnej i Turystyki, Wrocław, pp. 93-112. 
http://rcin.org.pl 